\title{
Response to Tomasz Zuradzki's 'Preimplantation genetic diagnosis and rational choice under risk or uncertainty'
}

\author{
Xavier Symons
}

Tomasz Zuradzki's recent article is a valuable contribution to bioethical discourse on preimplantation genetic diagnosis (PGD). His argument circumvents the non-identity problem that plagues other defences of PGD. He also offers an effective critique of Mark Walker's 'box game' argument for genetic testing.

Nevertheless, he seems wrong to assert that anyone should accept his argument, even if they 'believe embryos have full moral status and their right to life can never be balanced with any other social or individual benefits' ${ }^{1}$ Zuradzki believes that his argument concerning the 'hypothetical rationality' and 'patient autonomy' of embryos binds everyone-no ethical frameworks excepted-to endorse PGD in certain circumstances. ${ }^{1}$ Hence, he concludes his article by writing

Even if somebody perceives the freezing and subsequent destruction of the surplus embryos remaining after an in vitro procedure to the moral equivalent of killing adults, and thus sees potential parents who decide on PGD as just as immoral as the terrorists in the above example, she should still accept PGD as a method of embryo selection. ${ }^{1}$

Zuradzki fails to address the ethical argumentation of one key opponent of IVF-the Catholic Church. This is indeed highly unfortunate, considering Zuradzki is a bioethicist in a country where the statements of the Catholic Church have significant impact on medicoethical policy. The following remarks are not intended to be an endorsement of Catholic teaching on the matter, though I am sympathetic to this position. I simply wish to point out a shortcoming in Zuradzki's argumentation.

In the 2008 document Dignitas Personae, the Congregation for the Doctrine of the Faith (CDF) - the peak bioethical authority in the Church-wrote, 'All things considered, it needs to be recognised that the thousands of abandoned embryos represent a situation of injustice which in fact cannot be resolved'. ${ }^{2}$ The document considers possibilities like the adoption of embryos by married couples, but concludes: 'this proposal, praiseworthy with regard to the intention of respecting and defending human life, presents various problems not dissimilar to [any other form of surrogate motherhood]'. ${ }^{2}$

Most Catholic moral theologians have interpreted this as putting embryos in a situation of 'ethical limbo' - their ontological status is so removed from the natural order that they fall outside the moral universe of Christian ethics. ${ }^{\text {3-5 }}$

Returning to Zuradzki's paper, it seems to me that he misses this nuance in the Church's writings on the status of embryos. He claims that his reasoning is binding even on those who claim that early embryos have full moral status, and their right to life can never be balanced with any other 
social or individual benefits'. ${ }^{1}$ However, the aforementioned statements of the CDF go beyond this basic formulation of pro-life ethics.

Applying the theory of Dignitas Personae, it seems to me that an orthodox Catholic would not be obliged to choose PGD. The knowledge that a grave wrong would come of it-the only possible outcome considering the absurd existential state of the embryo-vitiates any moral obligation. ${ }^{\text {i. } 6}$ Appealing to 'honoring the patient autonomy' of the 'hypothetical rational agent' does not affect the position. In many cases, an orthodox Catholic ethics demands that one ignore a patient's desires-Catholic teaching on the performance of abortion is perhaps the most controversial example. PGD for serious illness is obviously linked to the selection of certain embryos over others. Due to this link, one would have no duty to perform or facilitate PGD. They would, in fact, have a duty to do the contrary.

Such a conclusion may be unpalatable, but as far as I can see, this is where this particular strand of pro-life ethics leads. Insofar as I am correct, Zuradzki's claim fails. Some positions remain unaffected by his proposed 'hypothetical preference-patient autonomy' argument. If his aim is to find a policy acceptable on all moral frameworks, his thesis needs to be fundamentally changed.

\section{Footnotes}

'Brugger's article ${ }^{3}$ also contains a summary of the minority opposing view.

ii An earlier Church, document, Donum Vitae, echoes Dignitas Personae when describing the "absurd fate" that embryos are exposed to. See reference 6.

\section{References}

1. Żuradzki T. Preimplantation genetic diagnosis and rational choice under risk or uncertainty. Journal of Medical Ethics. 2014;40:774-8.

2. Congregation for the Doctrine of the Faith. Instruction Dignitas Personae on certain bioethical $\begin{array}{llllll}\text { questions. } \quad \text { The } & \text { Soly } & 8 & \text { Sept } & \text { 2008, } & \text { n.19. }\end{array}$ http://www.vatican.va/roman_curia/congregations/cfaith/documents/rc_con_cfaith_doc_20081208 _dignitas-personae_en.html (accessed 24 May 2014).

3. Brugger EC. Symposium on Dignitas Personae. National Catholic Bioethics Center 2009;9:461-83.

4. Sarnecchia DB. Bioethics, law and human life issues. Lanham, MD: Scarecrow Press, 2010:159-60.

5. Pacholyczyk T. What should we do with frozen embryos? National Catholic Bioethics Center, 1 Jun 2009. http://www.ncbcenter.org/page.aspx?pid=478 (accessed 25 May 2014).

6. Congregation for the Doctrine of the Faith. Instruction on respect for human life in its origin and on the dignity of precreation: Replies to certain questions of the day. The Holy See, 22 Feb 1987, no. 5. http://www.vatican.va/roman_curia/congregations/cfaith/documents/rc_con_cfaith_doc_19870222 _respect-for-human-life_en.html (accessed 24th May 2014). 